Ann. Biol. anim. Bioch. Biophys., I975, 15 (2), 22I-23I.

\title{
OVULATION AND ENDOCRINE RESPONSE AFTER LH-RH IN DOMESTIC ANIMALS (1)
}

\author{
J. H. BRIT'T \\ Animal Reproduction Laboratory, Department of Dairy Science, \\ Michigan State University, \\ I:ast J.ansing, Michigan, 48824 (U. S. A.)
}

\section{SUMMARY}

Endocrine and ovulatory responses were examined after luteinizing hormone-releasing hormone (LH-RH) administration in cows with ovarian follicular cysts, in diestrous cows, in cows 2 weeks after parturition and in diestrous and proestrous heifers. Serum LH concentrations increased after LH-RH treatment and the greatest response was observed in cows with ovarian follicular cysts. Serum progesterone concentrations were increased at 6 hours after LH-RH in animals which had functional luteal tissue in the ovaries but serum estradiol and estrone were unchanged. Ovarian follicular cysts luteinized after LH-RH treatment in cows and estrous cycles were initiated in these animals. Ovulation was induced I day after LH-RH administration in cows 2 weeks after parturition, but was not induced after LH-RH treatment in diestrous heifers and cows or proestrous heifers. Results obtained in the bovine are discussed in relation to results after $\mathrm{LH}-\mathrm{RH}$ treatment in ewes, gilts and mares.

\section{INTRODUCTION}

Isolation of porcine (Scharly et al., I97I) and ovine (Amoss it al., I97I) luteinizing hormone/follicle stimulating hormone releasing hormone (LH-RH) FSH-RH) resulted in its rapid structural identification and synthesis (IIATSUO et al., I97 $\mathrm{r} a, b)$. Purified natural and synthetic LH-RH products were shown to have comparable LH-releasing activity in laboratory animals (SCHALIY ot al., I972 ; Burgus et al., I972), sheep (REEves et al., I970 ; ARIMURA et al., I972) and cattle (ZoLmax et al., I973). Much of this early work was recently reviewed by CONVEY (I973).

(1) Published with the approval of the Michigan Agriculture Experiment Station as Journal Article No 7020. The author acknowledges the contributions of E. M. Convi:, J. Zolman and R. J. KitTok in conducting the studies. 
After these initial studies, we began experiments to determine endocrine and ovulatory responses to $\mathrm{L}_{4} \mathrm{H}-\mathrm{RH}$ in cattle. In our studies gonadotropin releasing hormone (GnRH; Abbott I aboratories, North Chicago, Illinois) was used but will be referred to as LH-RH for uniformity in comparing our results with results of others who may have used different LH-RH preparations.

\section{MATERIALS AND METHODS}

\section{Experiment 1}

Serum hormone and ovarian structural changes after administration of LH-RH to five lactating Holstein cows with ovarian follicular cysts were compared with responses observed in four cows given LH-RH during diestrus (Kiтrok et al., 1973). Blood samples were collected on a schedule designed to detect acute and chronic changes in serum hormones after each animal was given three intravenous injections of LH-RH (roo $\mu \mathrm{g})$ at 2 hours intervals. Serum LH, progesterone and estrogens were quantified by radioimmunoassay and ovarian structural changes were monitored twice weekly by rectal palpation.

\section{Experiment II}

Endocrine and ovulatory responses were examined after LH-RH treatment in early postpartum dairy cows (BRITr et al., 1974). Twenty lactating Holstein cows were given LH-RH ( Ioo $\mu \mathrm{g}$ ) or saline via a No 5 gelatin capsule implanted in an ear on day $\mathrm{I}_{4}$ post-partum. Blood samples were collected from a jugular vein at frequent intervals from 2 hours before until 6 hours after treatment on day I 4 post-partum then on days I6, I8, 2I, 29, 3I, 32, 33, 34, and 35 post-partum and twice weekly thereafter until day 65 when the experiment terminated. Serum LH, progesterone and estrogens were quantified by radioimmunoassay and changes in ovarian structures were monitored by rectal palpation twice weekly until day 65 post-partum.

\section{Experiment III}

The effect of LH-RH on ovulation and estrous cycle length in heifers was examined. Twenty Holstein heifers approximately it months of age received no treatment or intramuscular administration of $200 \mu \mathrm{g}$ LH-RH on day I5, I 7 or I 9 of an estrous cycle. Blood samples were collected via tail venipuncture on alternate days from day i 5 until estrus or development of a new corpus luteum. Ovulation and corpus luteum development were monitored by palpation per rectum. Serum progesterone was quantified by radioimmunoassay according to LouIs et al., (1973).

\section{RESULTS}

\section{Experiment I}

Serum LH increased after each dose of LH-RH in luteal phase cows and cows with ovarian follicular cysts (fig. I). Peak LH response after each dose was twoto four-fold greater in cows with ovarian follicular cysts compared with cows treated during diestrus. Serum progesterone prior to first LH-RH injection averaged $0.9 \pm 0.4 \mathrm{ng} / \mathrm{ml}$ for cows with ovarian follicular cysts which was less than the comparable average $(5.9 \pm 0.8 \mathrm{ng} / \mathrm{ml})$ for luteal phase cows. However, mean serum estradiol $(9.4 \pm 3.1$ vs $8.8 \pm 0.7 \mathrm{pg} / \mathrm{ml})$ and estrone $(3.8 \pm 0.5 \mathrm{vs} 3.0 \pm 0.4$ 


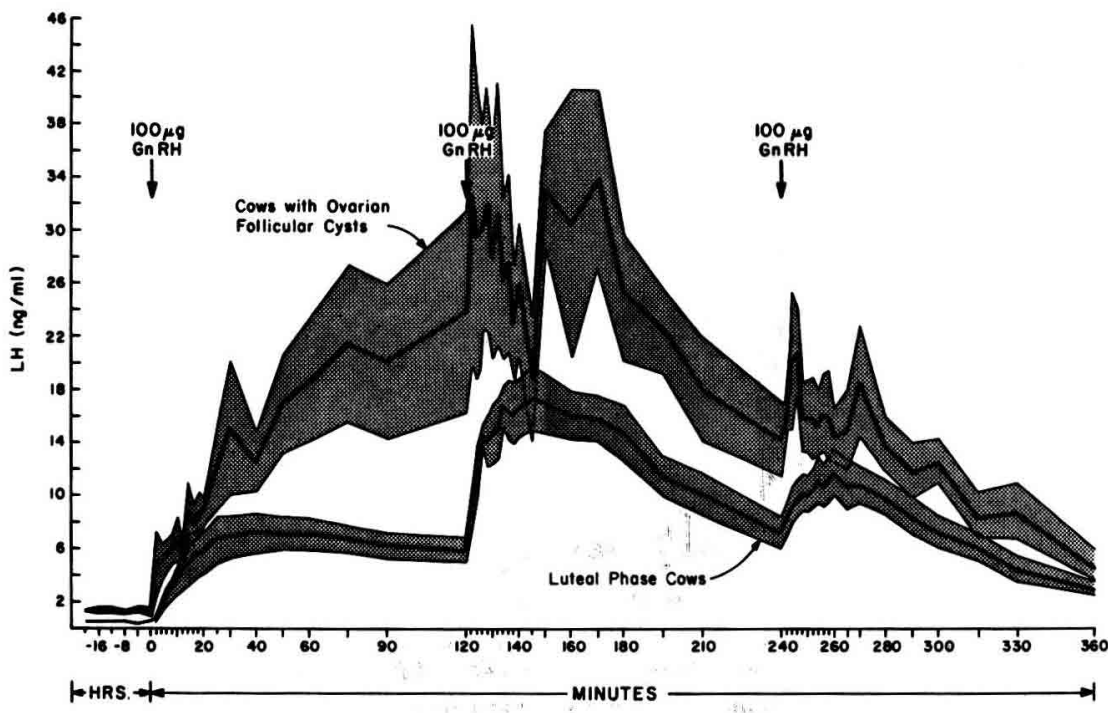

Iir. I. - Serum luteinizing hormone response after $L H-R H$ (Gin RH) in luteal phase conts and cows with ovarian follicular cysts

(Shaded area represents standard errors of the mean)

$\mathrm{pg} / \mathrm{mll}$ ) were not different in cows with ovarian follicular cysts compared with cows in diestrus. Serum progesterone peaked at I d days after LH-RH (fig. 2) and then declined according to a pattern characteristic of normal estrous cycles. One of five cows with ovarian follicular cysts ovulated after LH-RH treatment, four dereloped luteinized follicles and all five cows exhibited estrus 20 to 24 days after treatment. These results suggested that luteal tissue in the follicular cyst assumed the role of a functional corpus luteum in each of four cows in which a palpable corpus luteum was not detected.

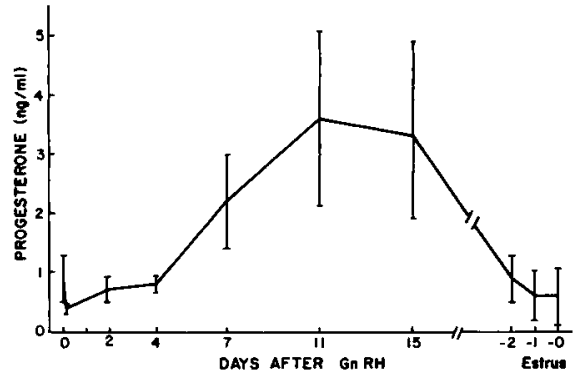

HIC. 2. - Chronic serum progesterone concentrations after L.H-RII (GuRH) in cows zith ovarian follicular cysts

(Vertical lines represent standard errors of the mean)

\section{Experiment II}

Serum $\mathrm{I}_{\mathrm{H}} \mathrm{H}$ in cows given $\mathrm{LH}-\mathrm{RH}$ on day $\mathrm{I} 4$ post-partum increased by $\mathrm{I}$ hour and remained elevated at 6 hours after treatment (fig. 3). Peak serum $\mathrm{L}_{\text {. }} \mathrm{H}$ ( ( $5.0 \pm \mathrm{r} .9 \mathrm{ng} / \mathrm{ml}$ ) occured at approximately 4 hours after LH-RH though blood samples were not collec- 
ted frequently enough to detect highest values in all animals. Serum LH concentrations were as high as $24.8 \mathrm{ng} / \mathrm{ml}$ in individual samples collected at 4 hours after LH-RH. Serum LH remained unchanged during 6 hours after cows were given gelatin capsule implants containing saline (fig. 3). Serum estrogens and progesterone were not acutely

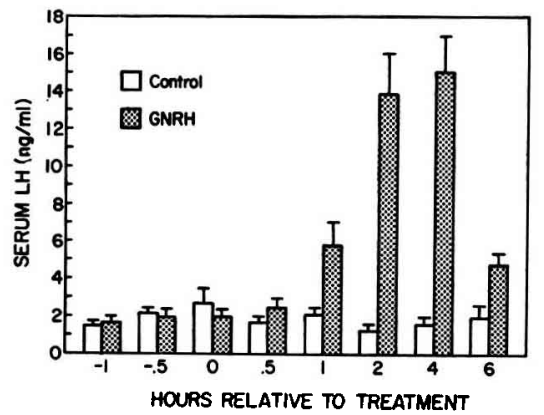

IIG. 3. - Serum luteinizing hormone response after LH-RH ((.ril RH)

or saline to lactating cows on day 14 post-partum

(Vertical lines represent standard errors of the mean)

affected in cows given $\mathrm{LH}-\mathrm{RH}$ on day $\mathrm{I}_{4}$ post-partum (table $\mathrm{I}$ ). The increase in serum estrone concentrations at 4 hours after $\mathrm{LH}-\mathrm{RH}$ or saline was due to peaks in individual samples from one or two animals in each group and was not related to LH-RH treatment $(\mathrm{P}>.05)$.

\section{TABI.E I}

Serum estrone, estradiol and progesterone at 0 and 4 or $6 \mathrm{hr}$ after $100 \mathrm{ug}$ I.H-RH (GnRH) on day post-partum

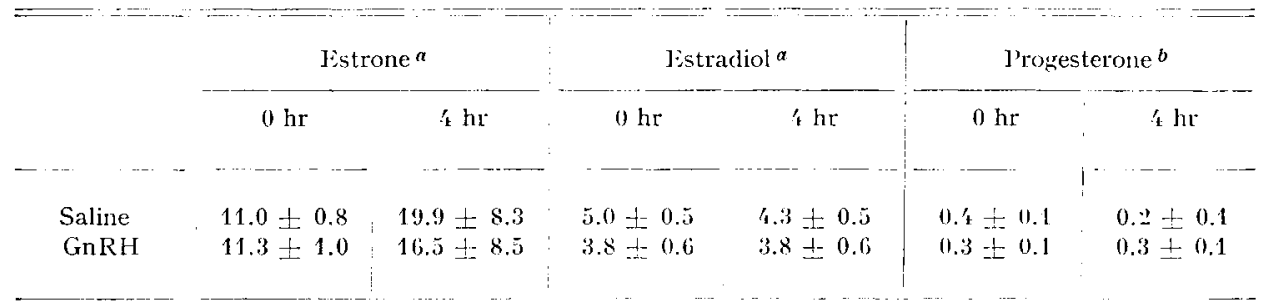

a: $\mathrm{pg} / \mathrm{ml} ; n=10$.

$b: n g / m l ; n=9$. One cow which had a functional corpus luteum was excluded.

One cow given $\mathrm{LH}-\mathrm{RH}$ on day $\mathrm{I}_{4}$ post-partum had ovulated on day 9, all others ovulated on day I5, I day after treatment. Thus, the average interval from parturition to first ovulation was $\mathrm{I} 4.4 \pm 0.6$ days for cows given $\mathrm{LH}-\mathrm{RH}$ compared with $23.6 \pm 2.6$ days for eight of Io cows given saline. Two given saline on day I4 postpartum developed ovarian follicular cysts and did not ovulate prior to day 65 when the experiment terminated. One cow given saline was diagnosed as having luteinized ovarian follicles even though she exhibited estrus at $2 \mathrm{I}$ day intervals beginning 
20 days after treatment. Progesterone in serum of this cow did not exceed $0.3 \mathrm{ng} / \mathrm{ml}$ until day $6_{5}$ post-partum.

Serum progesterone changes during 3 weeks after $\mathrm{I} / \mathrm{H}-\mathrm{RH}$ administration to cows on day 14 post-partum is depicted in figure 4. Although lower in magnitude,

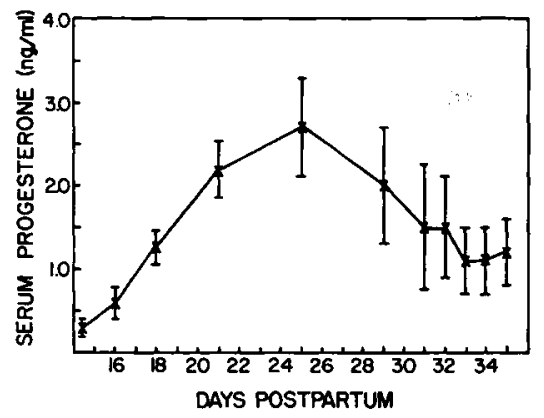

Tiri. 4. - Chronic serum progesterone concentrations after administration of $L H-R H$ ((in $\mathrm{RH})$ to lactating dairy cones on day $1+$ post-partum

(Vertical lines represent standard errors of the mean.

1)ata from one cow which had a functional corpus luteum is excluded)

the progesterone profile was similar to that during the bovine estrous cycle. Cows given LH-RH on day 14 post-partum averaged 3.I \pm o.I ovulations prior to day $6_{5}$ post-partum compared with $2.0 \pm 0.4$ ovulations for cows given saline (fig. 5).

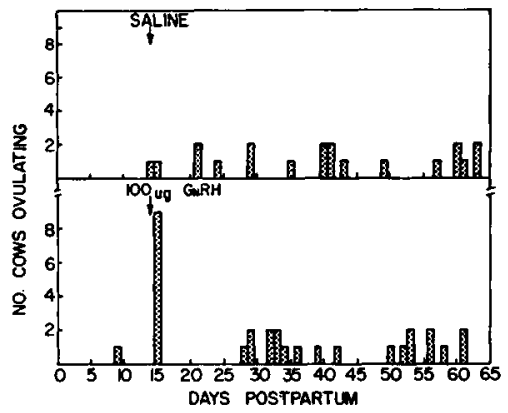

L'IG. 5. - Frequency of ovulation in lactating cows given $L H-R H(\mathrm{Gn} \mathrm{RH})$ or saline on day $1 \pm$ post-partum

( $n=$ Io for each treatment group)

The first post-partum ovulation in cows given $\mathrm{L}_{6} \mathrm{H}-\mathrm{RH}$ or saline on day $\mathrm{I}_{4}$ postpartum occurred most frequently on the ovary opposite the post-gravid uterine horn and was not affected by treatment. Interval from first to second ovulation in cows given LH-RH was I8.I \pm I.o days compared with $20.9 \pm 0.9$ days for cows given saline. None of the cows given $\mathrm{LH}-\mathrm{RH}$ exhibited estrus in association with the induced ovulation while 2 of 8 saline-treated cows were detected in estrus just prior to first ovulation. Interval from parturition to first estrus was $4 \mathrm{I} .0 \pm 4.0$ days for cows given LH-RH on day I4 post-partum compared with $37.5 \pm 4.0$ days for cows treated with saline. Thus, while LH-RH treatment resulted in a shorter interval from 
parturition to first ovulation, it did not shorten the interval to first estrus. However, all cows given $\mathrm{L} H-\mathrm{RH}$ exhibited regular ovarian cycles until day 65 post-partum while 3 of ro cows given saline manifested abnormal ovarian activity (ovarian follicular cysts or luteinized follicles) during this period.

\section{Experiment III}

Administration of $200 \mu \mathrm{g} \mathbf{L H}-\mathrm{RH}$ to heifers on day $\mathbf{5}, \mathbf{1} 7$ or $\mathbf{1 9}$ of an estrous cycle increased the variation in interval from previous estrus to subsequent estrus and ovulation. All saline injected heifers exhibited estrus prior to ovulation compared with 3 of 5,4 of 5 and 2 of 5 heifers given $\mathrm{L}_{\mathrm{H}-\mathrm{RH}}$ on day I5, I7 or I9 (fig. 6). The

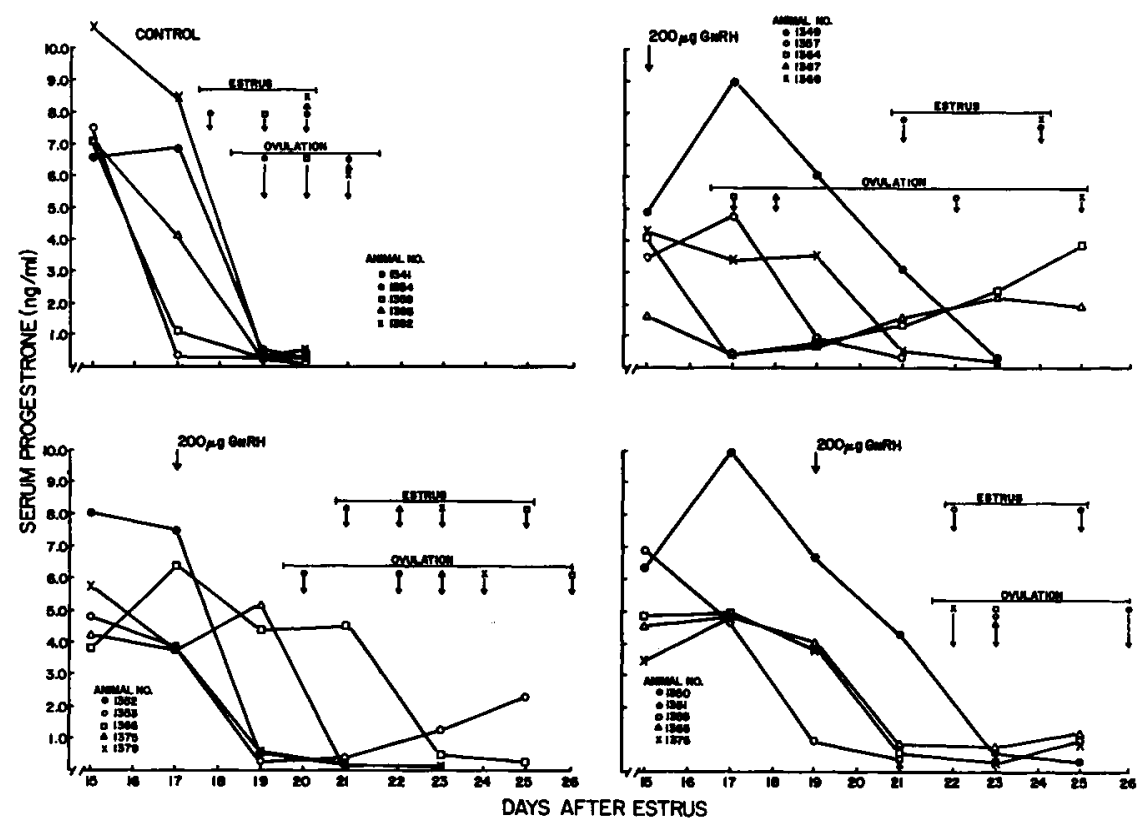

FiG. 6. - Serum progesterone concentrations,

time of estrus and time of ovulation in heifers given $L H-R H$ (GuRH) on days 15,17 or 19 of an estrous cycle

inter-ovulatory interval in saline injected heifers was $x 9.4 \pm 0.4$ days compared with $20.4 \pm$ I.7, 22.0 \pm I.o and $22.4 \pm 0.7$ days for heifers given $\mathrm{LH}-\mathrm{RH}$ on days I 5, I 7 or I9. In no case did ovulation occur on the day after $\mathrm{L}, \mathrm{H}-\mathrm{RH}$ administration ; however, when LH-RH was given on day $\mathrm{I}_{5}$ of an estrous cycle, day of subsequent ovulation ranged from $I 7$ to 25 of that cycle, compared with 20 to 26 and 22 to 26 for animals given LH-RH on days I7 or I9.

Serum progesterone concentration $(\mathrm{ng} / \mathrm{ml})$ averaged $0.3 \pm 0 . I$ on day $\mathrm{Ig}$ in saline injected heifers compared with $2.4 \pm$ I.0, 2.I \pm I.I and $3.8 \pm 0.9$ in heifers given $\mathrm{LH}_{\mathrm{H}} \mathrm{RH}$ on days I, I7 7 or I9 (fig. 6). Elevated serum progesterone on day I9 in each of 2 heifers given LH-RH on days $x_{5}$ or I 7 may be attributable to stimulation of luteal progesterone secretion in these animals. Results from heifers treated on day 
I9 are somewhat biased since only those which had estrous cycles greater than I9 days were included in this group.

\section{DISCUSSION}

\section{LH-RH in cattle}

Luteinizing hormore release after LH-RH has been examined during various physiological states in the bovine. Zolmax ct al., (I973) from our laboratory first reported that synthetic and purified porcine $\mathrm{LH}-\mathrm{RH}$ were capable of inducing $\mathrm{LH}$ release from bovine pituitary tissues in vitro, and that synthetic $\mathrm{LH}-\mathrm{RH}$ resulted in a dose-related increase in serum $\mathrm{LH}$ concentrations during early diestrus in heifers. Cows with ovarian follicular cysts released more $\mathrm{LH}$ after $\mathrm{LH}-\mathrm{RH}$ treatment than cows treated during diestrus (KITTOK et al., I973). This indicated that responsiveness of the pituitary to LH-RH varied with physiological state of the animal. Thus ZoLman et al., (I974) administered LH-RH to heifers during diestrus or proestrus and observed that serum $\mathrm{LH}$ response to $\mathrm{LH}-\mathrm{RH}$ was positively related to pretreatment serum level of estradiol and estrone; a greater response occurred in animals with higher estrogen concentrations.

Serum FSH also increased after LH-RH in the bovine and peak response occurred simultaneously with the LH-peak (AKBAR et al., I974; KALTENBACH et al., I974; ZoLMAN and CoNVEY, I973). However, peak serum FSH after LH-RH was only two-to four-fold higher than pretreatment values compared with twenty-fold or more increases in serum LH.

BIERsCHWAI et al., (I974) administered varying doses of LH-RH to II4 cows with ovarian follicular cysts and reported that 74 percent of the treated cows developed luteinized ovarian follicles. A similar response after $\mathrm{LH}_{\mathrm{H}} \mathrm{RH}$ treatment in $\mathrm{I}_{5}$ cows with ovarian follicular cysts was observed by GRUNERT et al., (I973). Thus our initial observation (KITTOK et al., I973) that LH-RH was effective in initiating estrous cycles in cows with follicular cysts has been verified in clinical studies.

Our observation that LH-RH caused LH release and ovulation in post-partum dairy cows (BRITr et al., I974) suggests that LH-RH may be used to initiate ovarian cycles in lactating animals. A similar observation was reported by ScHAMS et al., (I973) who gave $\mathrm{I} 5 \mathrm{OO} \mu \mathrm{g} \mathrm{L}, \mathrm{H}-\mathrm{RH}$ to each of 6 cows between day $\mathrm{I} 2$ and $\mathrm{I} 8$ post-partum and observed ovulation in all animals I day after treatment. However, these authors did not provide data on the time of ovulation during a similar post-partum interval in non-treated cows. Since post-partum anestrus in lactating cows prohibits their response to luteolytic agents such as prostaglandin $F_{2 \alpha}$ it is possible that administration of $\mathrm{LH}-\mathrm{RH}$ can be used to induce $\mathrm{LH}$ release and ovulation in order to provide a common physiological state for synchronization of ovulation in these animals.

Apparently ovulation in the bovine can not be induced by treatment with LHRH if a functional corpus luteum is present. The reason for this lack of response during diestrus is not known but may result from an inhibitory action of progesterone on ovulation. 


\section{LH-RH in sheep}

REEVES et al., (I970, I97I) first demonstrated that highly purified porcine LH-RH induced $\mathrm{LH}_{\mathrm{H}}$ release in ewes and that a greater response occurred on the day of estrus relative to other days of the estrous cycle. As in the bovine, LH-RH administration to ewes also caused an increase in serum FSH (REEVES et al., I972; JonAs et al., I973; Symons et al., I974). Ovulation has been observed after LH-RH treatment in anestrous ewes (REEVES et al., I972, I974; HARESIGN ct al., I973; RIPPEI, it al., I974 $b$; KINDER et $a l .$, I974) in lactating ewes (RESTAI.L and RADFORD, I974), in diestrous ewes (RIPPEL, et al., I974 $a, b$ ) and in ewes after cessation of progesterone injections (SERGERSON ct al., I974). CRIGHTON et al., (I973) reported that only 3 of 8 ewes had functional corpora lutea Io to $\mathbf{I} 3$ days after induction of ovulation with LH-RH, even though all eight ewes had observable ovulation points two days after treatment. Thus while the $L_{1} H$ release after $L_{H} H-R H$ resulted in ovulation in anestrous ewes, functional capabilities of the resultant corpora lutea were reduced.

SERGERSOx et al., (1974) reported reduced fertility in ewes given LH-RH after synchronization with progesterone. They attributed this reduction in fertility to a block of sperm transport presumably caused by a decrease in estrogen secretion after LH-RH. Thus synchronization of ovulation with $\mathrm{LH}-\mathrm{RH}$ in combination with other agents may result in reduced fertility if there is an alteration in steroid secretion around estrus.

\section{LH-RH in swine}

ChakraborTy at al., (r973) observed serum LH peaks in preputertal gilts I 5 or 30 min after each of $16 \mathrm{LH}-\mathrm{RH}$ injections given at 6 hours intervals. BAKER et al., (I973, I974) first reported ovulation after LH-RH treatment in prepubertal gilts primed with pregnant mare serum gonadotropin (PMS) ; however, the percent of gilts ovulating after I, 5 or Io $\mathrm{mg} \mathrm{LH}-\mathrm{RH}$ was lower than that observed in PMSprimed gilts given human chorionic gonadotropin (HCG). In contrast, RAMPACEK et al., (I974) found that I5 of I8 PMS-primed prepubertal gilts ovulated when given I $25 \mu \mathrm{g} \mathrm{LH}-\mathrm{RH}$ at 72 or $9 \mathrm{I} .5$ hours after PMS treatment. However, they observed that only 5 of $I_{5}$ gilts which ovulated and were inseminated were pregnant 25 days later. Based on progesterone concentrations in serum samples collected frequently during two weeks after LH-RH treatment, they concluded that gilts which were nonpregnant failed to maintain functional corpora lutea. Thus the prepubertal gilt like the anestrous ewe may require sustained luteotropic stimulation in order to maintain corpora lutea induced by LH-RH treatment.

\section{LH-RH in the mare}

GiNTHER and WENTWORTH (I974) gave $400 \mu \mathrm{g}$ LH-RH to mares in late anestrus or on the second day of estrus and observed a rapid increase in serum LH, but follicular development or interval from the onset of estrus to ovulation was not affected. Similarly, Downey et al., (I974) injected mares with I mg LH-RH on the second day of estrus and found no change in the interval from onset of estrus to ovulation 
though duration of estrus was reduced by 2 days. However, when they gave mares $2 \mathrm{mg} \mathrm{LH}-\mathrm{RH}$ on the second day of estrus and on each subsequent day until ovulation the interval from onset of estrus to ovulation and duration of estrus were reduced.

\section{CONCLUSIONS}

I. $\mathrm{LH}-\mathrm{RH}$ is a potent releaser of $\mathrm{LH}$ and $\mathrm{FSH}$ in domestic animals.

2. Changes in serum hormone concentrations after LH-RH treatment vary with species and physiological state of treated animals.

3. LH-RH can be used to initiate estrous cycles in cows with ovarian follicular cysts.

4. LH-RH treatment causes ovulation in cows when given two weeks after parturition but not when given during diestrus.

\section{Colloque : Control of sexual cycles in domestic animals \\ October 27-30, 1974, Nouzilly.}

\section{RÉSUMÉ,}

\section{RÉPONSE ENDOCRINIENNE ET OVULATION APRÈS ADMINISTRATION DE LH-RH CHEZ LES ANIMAUX DOMESTIQUES}

Les réponses endocriniennes et ovulatoires ont été examinées après l'administration de l'hormone activant la sécrétion de LH (LH-RH) à des vaches :

I) ayant des kystes follicullaires ovariens,

2) étant au stade dicestrus,

3) à deux semaines post-partum,

4) à des génisses au stade diœstrus et proostrus.

Les concentrations en $\mathrm{LH}$ dans le sérum sanguin ont augmenté après le traitement par LH-RH et la réponse la plus marquée a été observée chez les vaches ayant des kystes folliculaires ovariens. Les concentrations en progestérone dans le sérum ont augmenté 6 heures après l'administration du LH-RH chez les animaux ayant du tissu lutéal fonctionnel dans les ovaires mais le niveau d'œstradiol et d'œstrone dans le sérum est resté inchangé. Les kystes folliculaires ovariens se sont lutéinisés après l'administration du LH-RH chez les vaches et les cycles œestriens ont été induits chez ces mêmes animaux. L'ovulation a été provoquée un jour après l'administration du LH-RH chez les vaches à deux semaines post-partum mais elle n'a pas été observée chez les génisses et les vaches en diœestrus ou chez les génisses en proostrus traitées par LH-RH. Les résultats obtenus chez les bovins sont discutés en comparaison avec ceux obtenus chez les brebis, les truies et les juments après le traitement par l'hormone LH-RH.

\section{REFERENCES}

Akbar A. M., Reichert L. E., Dunn T. G., Kaltenbach C. C., Niswender G. D., I974. Serum levels of follicle stimulating hormone during the bovine estrous cycle. J. Anim. Sci., 39, 360-365.

Amoss M., Burges R., Blackwell R., Vale W., Fellows R., Guillemin R., I97i. Purification, amino acid composition and $\mathrm{N}$-terminus of the hypothalamic hormone releasing factor (LRF) of ovine origin. Biochem. Biophys. Res. Comm., 44, 205-210. 
Arimura A., Debeljuk L., Matsuo H., Schally A. V., r972. Release of luteinizing hormone by synthetic LH-releasing hormone in the ewe and ram. Proc. Exp. Biol. Med., 139, 85I-854.

Baker R. D., Downey B. R., BRINkLey H. J., I973. Induction of ovulation in pigs with gonadotrophin releasing hormone. J. Anim. Sci., 37, I 376-1 379 .

Baker R. D., Shaw G. A., Downey B. R., I974. Effect of PMSG + HCG or GnRH on ovulation in gilts. J. Anim. Sci., 39, I97.

Bierschwal C. J., Garverick H. A., Martin C. E., Youngquist R. S., Cantley T. C., Brown M. D., I974. Clinical response of dairy cows with cystic ovaries to GnRH. J. Anim. Sci., 35, 199 .

Britt J. H., Kittok R. J., Harrison D. S., I974. Ovulation, estrus and endocrine response after GnRH in early post-partum cows. J. Anim. Sci., 39, 915-9r9.

Burgus R., Butcher M., Amoss M., Ling N., Monahan M., Rivier J., Fellows R., Blackwell R., Vale W., Gulllemin R., r972. Primary structure of the ovine hypothalamic luteinizing hormone-releasing factor (LRF). Proc. Natl. Acad. Sci., 69, 278-282.

Chakraborty P. K., Reeves J. J., Arimura A., Schally A. V., 1973. Serum LH levels in prepubertal female pigs chronically treated with synthetic luteinizing hormone releasing hormone/folliclestimulating hormone-releasing hormone (LH-RH/FSH-RH). Endocrinology, 92, 55-6r.

Convey E. M., 1973. Neuroendocrine relationships in farm animals : a review. J. Anim. Sci., 37, 745-757.

Crighton D. B., Foster J.P., Haresign W., Haynes N. B., Lamming G. E., I973. The effects of a synthetic preparation of gonadotrophin releasing factor on pituitary and ovarian function in anestrous ewes. J. Physiol. (Lond.), 231, 98-99 p.

Downey B. R., Irvine D. S., Parker W. G., Sullivan J. J., I974. Estrus and ovulation time in GnRH treated mares. J. Anim. Sci, 39, 206.

Ginther O. J., Wentworth B. C., 1974. Effect of a synthetic gonadotrophin-releasing hormone on plasma concentrations of luteinizing hormone in ponies. Am. J. Vet. Res., 35, 79-8I.

Grunert V. E., Muller-Schlosser F., Ahlers D., 1973. Beitrag zur behandlung von ovarialzystem des rindes mit einem synthetischen LH/FSH-releasing hormon. Dtsch. Tierarztl. IVschr., 80, $469-47 \mathrm{I}$.

Haresign W., Haynes N. B., Lamming G. E., I973. The effects of synthetic gonadotrophin-releasing factor on ovarian function in anestrous ewes. J. Reprod. Fert, 35, 600-601.

Jonas H. A., Salamonsen L. A., Burger H. G., Chamley W. A., Cumming I. A., Findlay J. K., Goding J. R., I973. Release of FSH after administration of gonadotrophin-releasing hormone or estradiol to the anestrous ewe. Endocrinology, 92, 862-865.

Kaltenbach C. C., Dunn T. G., Kiser T. E., Corah L. R., Akbar A. M., Niswender G. D., I974. Release of FSH and LH in beef heifers by synthetic gonadotrophin releasing hormone. J, Anim. Sci., $38,357 \cdot 362$.

Kinder J. E., Adams T. E., Chakraborty P. K., Reeves J. J., i974. Ovulation induction in the anestrous ewe. J. Anim. Sci., 38, 1337.

Kittok R. J., Britt J. H., Convey E. M., I973. Endocrine response after GnRH in luteal phase cows and cows with ovarian follicular cysts. J. Anim. Sci., 37, 985-989.

Louis T. M., Hafs H. D., Seguin B. E., I973. Progestrone, LH, estrus and ovulation after prostaglandin $\mathrm{F}_{2 \alpha}$ in heifers. Proc. Soc. Exp. Biol. Med., 143, I52-I55.

Matsuo H., Arimura A., Nair R. M. G., Schally A. V., I97I $a$. Synthesis of the procine LH and FSH releasing hormone by the solid phase method. Biochem. Biophys. Res. Comm., 45, $822-827$.

Matsuo H., Baba Y., Nair R. M. G., Arimura A., Schally A. V., ig7i $b$. Structure of the procine LH and FSH releasing hormone. I. The proposed amino acid sequence. Biochem. Biophys. Res. Comm., 43, I334-1 339 .

RampaceK G. B., Ulberg L. C., Fellows R. E., 1974. Function of induced CL in prepubertal gilts. J. Anim. Sci., 39, 222.

Reeves J. J., Arimura A., Schally A. V., I970. Studies on dose response relationship of luteinizing hormone-releasing hormone (LH-RH) in sheep. J. Anim. Sci., 31, 933-936.

Reeves J. J., Arimura A., Schally A. V., I97I. Pituitary responsiveness to purified luteinizing hormone-releasing hormone (LH-RH) at various stages of the estrous cycle in sheep. J. Anim. Sci. 32, 123-1 26.

Reeves J. J., Arimura A., Schally A. V., Kragt C. L., Beck T. W., Casey J. M., I972. Effects of synthetic luteinizing hormone-releasing hormone (LH-RH/FSH-RH) on serum LH, serum FSH and ovulation in anestrous ewes. J. Anim. Sci., 5, 84-89.

Reeves J. J., Tarnavsky G. K., Charkraborty P. K., i974. Serum LH in ewes treated with synthetic luteinizing hormone-releasing hormone/follicle stimulating hormone-releasing hormone (LH-RH) FSH-RH) at three periods of anestrus. J. Anim. Sci., 38, 369-373.

Restall B. J., Radford H. M., I974. The induction of reproductive activity in lactating ewes with gonadotrophin-releasing hormone (GnRH). J. Reprod. Fert., 36, 475-476.

Rippel R. H., Johnson E. S., Nauer R. E., Webel S. ig74a. Response of the luteal-phase ewe to GnRH. J. Anim. Sci., 39, 224 . 
Rippel R. H., Moser R. H., Johnson E.S., Mauer R. E., I974 $b$. Response of the ewe to synthetic gonadotrophin releasing hormone. J. Anim. Sci., 38, 605-6r 2.

Schally A. V., Arimura A., Baba Y., Nair R. M. G., Matsuo H., Redding T. W. Debel* JUK L., White W. F., I97I. Isolation and properties of the FSH and LH-releasing hormone. Biochem. Biophys. Res. Comm., 43, 393-399.

Schally A. Y., Redding T. W., Matsuo H., Ariumura A., 1972. Stimulation of FSH and LH release in vitro by natural and synthetic LH and FSH releasing hormone. Endocrinology, 90, I56I-I568.

Schams D., Hofer F., Hoffman B., Ender M. L., Karg H., i973. Effects of synthetic LH-RH treatment on bovine ovarian function during estrous cycle and post-partum period. Acta. Endocr. (Kbh.), Suppl., 177, 296.

Sergerson E. C., Ulberg L. C., Martin J. E., Fellows R. E., i974. Fertility in ewes treated with luteinizing hormone-releasing factor. Proc. Exp. Biol. Med., 146, 518-52I.

Srmons A. M., Cunningham H. F., SabA N., i974. The gonadotrophin hormone response of anestrous and cyclic ewes to synthetic luteinizing hormone-reasing hormone. J. Reprod. Fert., 39, II-2I.

Zolman J., Convey E. M., I973. GnRH : Effect on serum FSH and androgens in bulls. J. Anim. Sci, 37, 334-335.

Zolman J., Convey E. M., Britt J. H., I974. Relationships between the luteinizing hormone response to gonadotrophin releasing hormone and endogenous steroids. J. Anim. Sci., 39, 355-359.

Zolman J., Convey E. M., Britt J. H., Hafs H. D., I973. Release of bovine luteinizing hormone by purified porcine and synthetic gonadotrophin releasing hormone. Proc. Soc. Exp. Biol. Med., 142, I 89 -I 93 . 